\title{
Novel stability-indicating RP-UPLC method for simultaneous estimation of sitagliptin and ertugliflozin in bulk and pharmaceutical formulations
}

\author{
Ramya kuber $\mathrm{B}^{1 *}$ and Swetha Addanki ${ }^{2}$
}

\begin{abstract}
Background: The present investigation was proposed to develop a simple, sensitive, rapid, accurate, precise stability-indicating RP-UPLC method for simultaneous estimation of sitagliptin and ertugliflozin. Chromatographic separation was performed with Waters Hibar C $8[100 \times 2.1 \mathrm{~mm}, 2 \mu]$ column and mobile phase acetonitrile: water $(\mathrm{pH}$ 3.5) $[50: 50 \%, v / v]$, pumped at a flow rate $0.2 \mathrm{ml} / \mathrm{min}$. The separated analytes were detected with a UV detector at a wavelength of $218 \mathrm{~nm}$.

Results: The separation of sitagliptin and ertugliflozin was done at a retention time of $0.859 \mathrm{~min}$ and $1.570 \mathrm{~min}$, respectively. The present method was validated according to the $\mathrm{ICH}$ guidelines Q2 R1, and stability-indicating studies were carried out as per ICH guidelines Q1A R2. Intra-day and inter-day precision were found to be within acceptable limits. The linearity of the proposed method was in the concentration range of $25-125 \mu \mathrm{g} / \mathrm{ml}$ and $3.75-$ $22.5 \mu \mathrm{g} / \mathrm{ml}$ for sitagliptin and ertugliflozin, respectively. Limit of detection (LOD) and limit of quantification (LOQ) were found to be $0.5 \mu \mathrm{g} / \mathrm{ml}$ and $1.53 \mu \mathrm{g} / \mathrm{ml}$ for sitagliptin and $0.13 \mu \mathrm{g} / \mathrm{ml}$ and $0.38 \mu \mathrm{g} / \mathrm{ml}$ for ertugliflozin, respectively. The recovery of the method was found in between $99.7 \%$ and $100.7 \%$.

Conclusion: The proposed method was able to distinguish the analytes from by-products. Hence, the method was successfully implied for stability-indicating studies and for routine examination of sitagliptin and ertugliflozin in pharmaceutical formulation.
\end{abstract}

Keywords: UPLC, ICH guidelines, Validation, Sitagliptin, Ertugliflozin, Forced degradation studies

\section{Background}

Type 2 diabetes mellitus (T2DM) is a chronic disease characterized by hyperglycemia in which insulin resistance decreased and pancreatic $\beta$ cell function was disrupted. Sitagliptin, chemically called as (2R)-4-oxo-4[3-(trifluoromethyl)-5,6-dihydro[1,2,4] triazolo[4,3-a]pyrazin$7(8 \mathrm{H})$-yl]-1-(2,4,5-trifluorophenyl)butan-2-amine, is the first DPP-4 (Dipeptidyl peptidase) inhibitor, approved for treatment of T2DM by FDA in Oct 2006. It exerts pleiotropic

\footnotetext{
* Correspondence: swetha.addanki06@gmail.com

'Department of Pharmacognosy, IPT, SPMW, Tirupati, Andhra Prade sh-517501, India

Full list of author information is available at the end of the article
}

effects like diuretic and natriuretic actions by restoring GLP-1 that provides reno-protective action and anti-apoptotic, anti-fibrotic, anti-inflammatory, and anti-oxidant effects [1-3]. Gliflozins are novel SGLT2 inhibitors, which inhibit glucose reabsorption into plasma by inhibiting SGLT2 located at S1 and S2 segments of proximal renal tubules. Ertugliflozin, chemically called as $(1 \mathrm{~S}, 2 \mathrm{~S}, 3 \mathrm{~S}, 4 \mathrm{R}, 5 \mathrm{~S})-5$-[4-Chloro-3-(4ethoxy benzyl) phenyl]-1-hydroxy methyl 6,8 dioxabicyclo [3,2,1] octane-2,3,4-triol, is a new class of gliflozin, which inhibit SGLT2 and used for the treatment of T2DM. It also lowers S.B.P. and D.B.P. and enhances energy loss, which results in weight loss. 


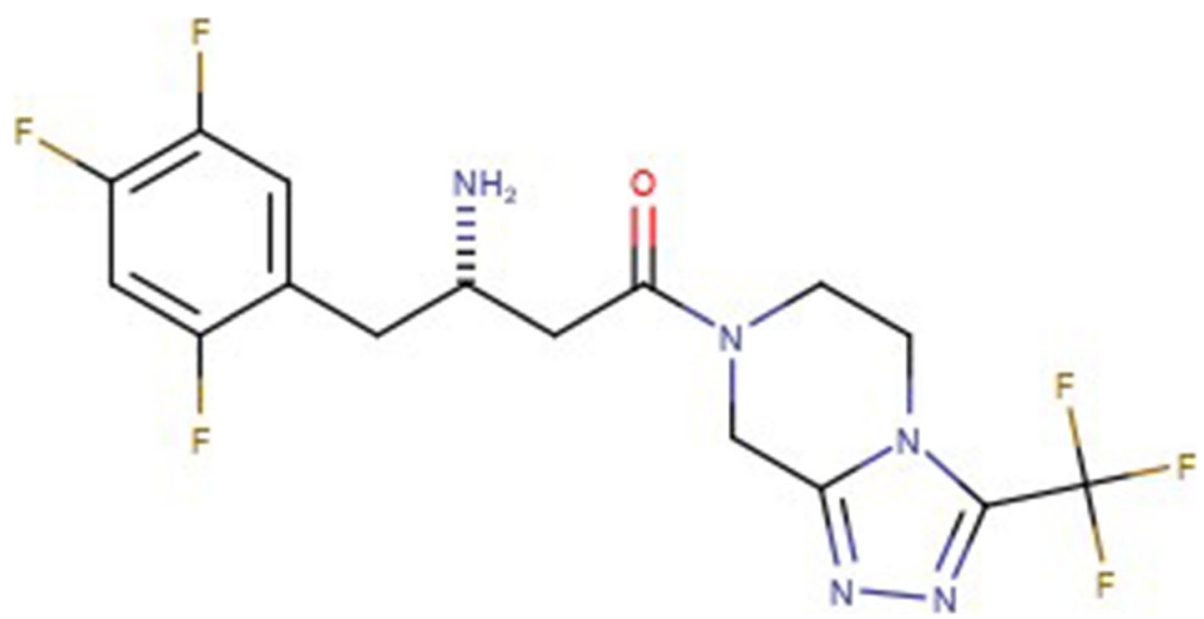

Fig. 1 Chemical structure of sitagliptin

The novel combination of SIT and ERT, along with diet and exercise, is adopted for the management of T2DM $[4,5]$.

A literature survey conveyed that limited methods were developed for the simultaneous estimation of sitagliptin and ertugliflozin. A few articles were reported spectroscopy, HPLC, and LC-MS for the determination of SIT and ERT, alone and in combination with other drugs. Few spectroscopic methods were reported for the determination of sitagliptin with other drugs [6]. Few HPLC methods were reported for the determination of SIT alone and in combination with other drugs [7-13]. One HPLC method was reported for the determination of ertugliflozin with metformin [14]. One method was reported for simultaneous estimation of SIT and ERT in bulk and dosage form by HPLC method using mobile phase acetonitrile: water $(\mathrm{pH}$ 3.5) [50:50\%, v/v] [15]. Few LC-MS methods were reported for the determination of sitagliptin and metformin in human plasma [16, 17]. However, there were no reported methods available for the simultaneous determination of SIT and ERT using RP-UPLC. To our knowledge, this is the first report of a stability-indicating RP-UPLC method for the estimation of SIT and ERT in bulk and pharmaceutical formulations. The present investigation aims to develop stability-indicating reverse-phase ultra-performance liquid chromatography (RP-UPLC) method for simultaneous estimation of SIT, ERT in bulk, and pharmaceutical formulations. ICH Q2R1 guideline suggested the validation of analytical procedure and acceptance criteria of validation parameters [18]. ICH Q1A(R2) guideline recommended that stability testing of new drug products expedite the identification of degradation products and the inherent stability

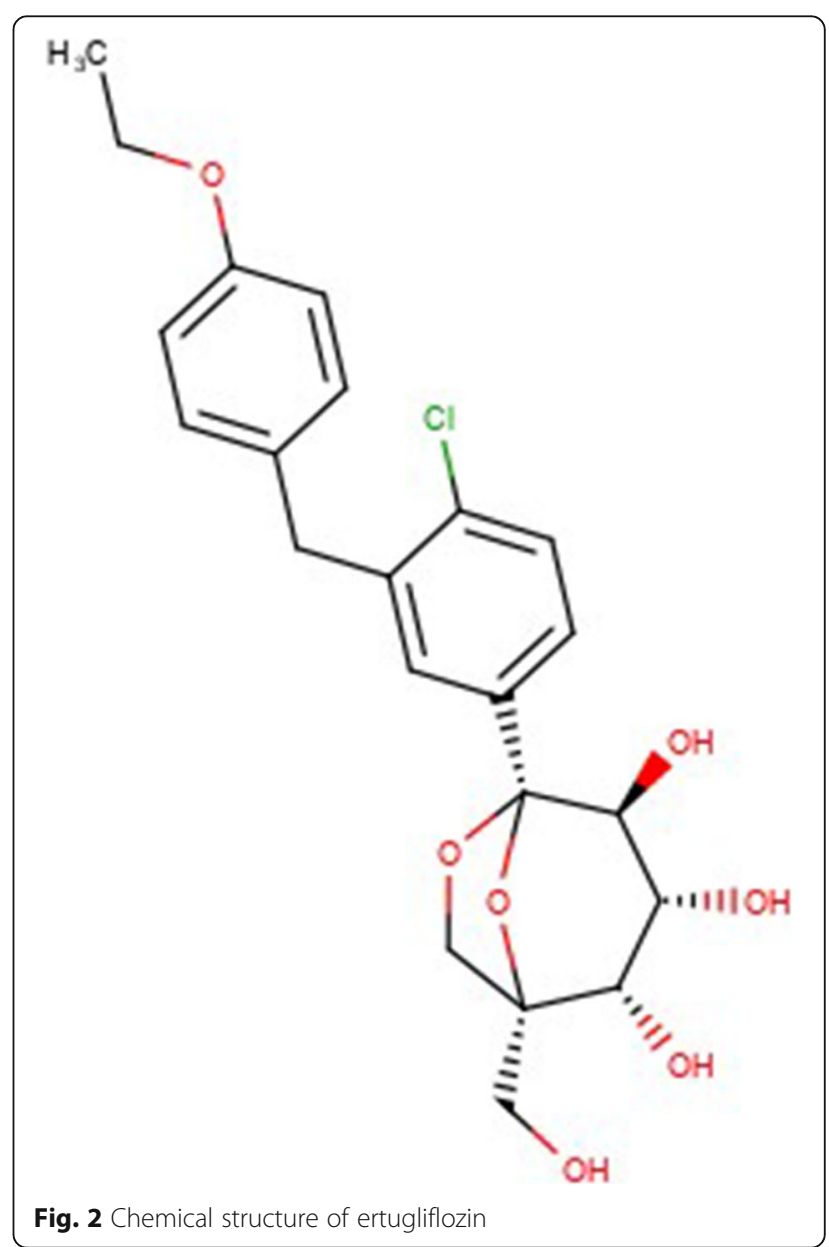


Table 1 Different trails

\begin{tabular}{|c|c|c|c|c|}
\hline Trail & Column & Mobile phase(\% v/v) & Flow rate & Observation \\
\hline 1 & STD Hibra C18 [100×2.1mm, $2 \mu \mathrm{m}]$ & Aceonitrile to water (50:50) & $0.3 \mathrm{ml}$ & Assymetric peak with lower efficiency for sitagliptin \\
\hline 2 & STD CHS C18 [100×2.1mm, $2 \mu \mathrm{m}]$ & Water to acetonitrile (50:50) & $0.3 \mathrm{ml}$ & The tailing factor of sitagliptin is very close to acceptance limit \\
\hline 3 & STD Hibra C8[100×2.1 mm, $2 \mu \mathrm{m}]$ & $\begin{array}{l}\text { Acetonitrile to water ( } \mathrm{pH} 3.5) \\
(50: 50)\end{array}$ & $0.2 \mathrm{ml}$ & $\begin{array}{l}\text { Symmetric peak with higher efficiency and acceptable tailing } \\
\text { factor }\end{array}$ \\
\hline
\end{tabular}

$v / v$ volume by volume, STD standard, CHS charged surface hybrid, $\mathrm{mm}$ millimeter, $\mathrm{m} /$ milliliter, $\%$ percentage, $\mu m$ micrometer

characteristics of the analyte. Stability-indicating analytical method can resolve analyte and its degradation products effectively [19]. The chemical structure of SIT and ERT was represented in Figs. 1 and 2.

\section{Methods}

A standard sample of SIT and ERT was procured from Fortune Pharma Pvt., Ltd., Hyderabad. HPLC grade acetonitrile, water, and methanol were procured from Merck Specialties Private Limited, Mumbai, India.

\section{UPLC instrument}

Acquity UPLC SYSTEM was equipped with quaternary pumps, ACQUITY TUV detector, and autosampler integrated with Empower 2 software.

\section{Preparation of standard solution}

$100 \mathrm{mg}$ of SIT and $15 \mathrm{mg}$ of ERT were weighed accurately into a $100-\mathrm{ml}$ volumetric flask and diluted with $50 \mathrm{ml}$ diluent and sonicated for $10 \mathrm{~min}$ and finally diluted up to the mark with diluent. Calibration standards were prepared by serial dilution of stock solution of SIT and ERT $0.25 \mathrm{ml}, 0.5 \mathrm{ml}, 0.75 \mathrm{ml}, 1 \mathrm{ml}$, $1.25 \mathrm{ml}$, and $1.5 \mathrm{ml}$ with diluent in a $10-\mathrm{ml}$ volumetric flask to produce a calibration concentration about 25, $50,75,100,125$, and $150 \mu \mathrm{g} / \mathrm{ml}$ of SIT and $3.75,7.5$, $11.25,15,18.75$, and $22.5 \mu \mathrm{g} / \mathrm{ml}$. The solution with $100 \mu \mathrm{g} / \mathrm{ml}$ of SIT and $15 \mu \mathrm{g} / \mathrm{ml}$ of ERT was considered as a standard solution, and it was scanned in the UV wavelength region to determine the absorption maximum of $218 \mathrm{~nm}$.

\section{Preparation of sample solution}

In commercially available Steglujan (15mg Ertugliflozin and $100 \mathrm{mg}$ Sitagliptin), ten tablets were weighed accurately and triturated in a mortar and pestle into a fine powder. Accurately weighed powder equivalent to $100 \mathrm{mg}$ of SIT and $15 \mathrm{mg}$ of ERT were transferred into a $100-\mathrm{ml}$ volumetric flask. Approximately $70 \mathrm{ml}$ of diluent was added and sonicated for $10 \mathrm{~min}$, to completely dissolve SIT and ERT in the presence of other excipients in the formulation. Finally, the volume was made up to the mark with diluent. An aliquot of $1 \mathrm{ml}$ of the above solution was filtered through ALL PURE hydrophilic PVDF filter membrane of $0.45 \mu \mathrm{m}$ and was further diluted to $10 \mathrm{ml}$ with diluent to produce a concentration of $100 \mu \mathrm{g} / \mathrm{ml}$ and $15 \mu \mathrm{g} / \mathrm{ml}$ of SIT and ERT, respectively.

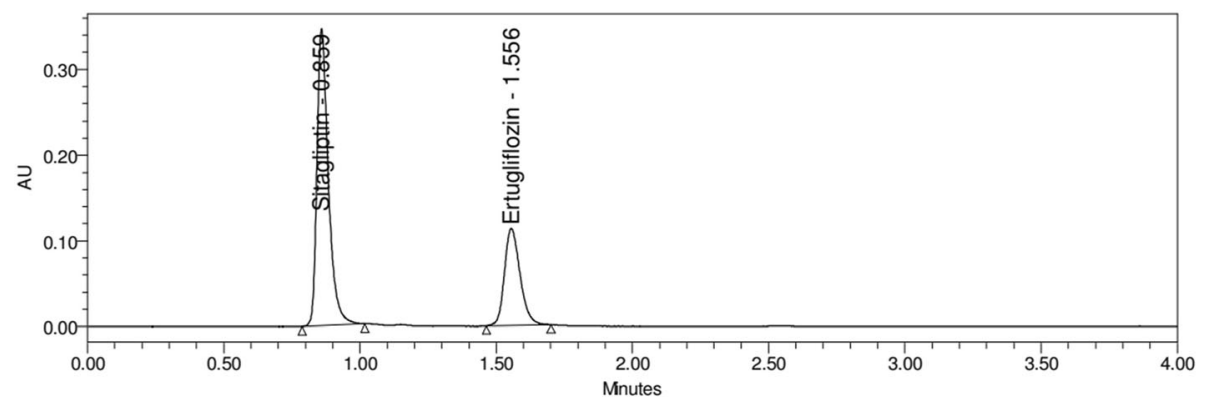

\begin{tabular}{|c|c|c|c|c|c|}
\hline Peak Name & RT & Area & $\begin{array}{c}\text { USP Plate } \\
\text { Count }\end{array}$ & USP Tailing & $\begin{array}{c}\text { USP } \\
\text { Resolution }\end{array}$ \\
\hline Sitagliptin & 0.859 & 987334 & 2458 & 1.45 & - \\
\hline Ertugliflozin & 1.556 & 448334 & 3673 & 1.23 & 7.7 \\
\hline
\end{tabular}

Fig. 3 Chromatogram of standard solution 


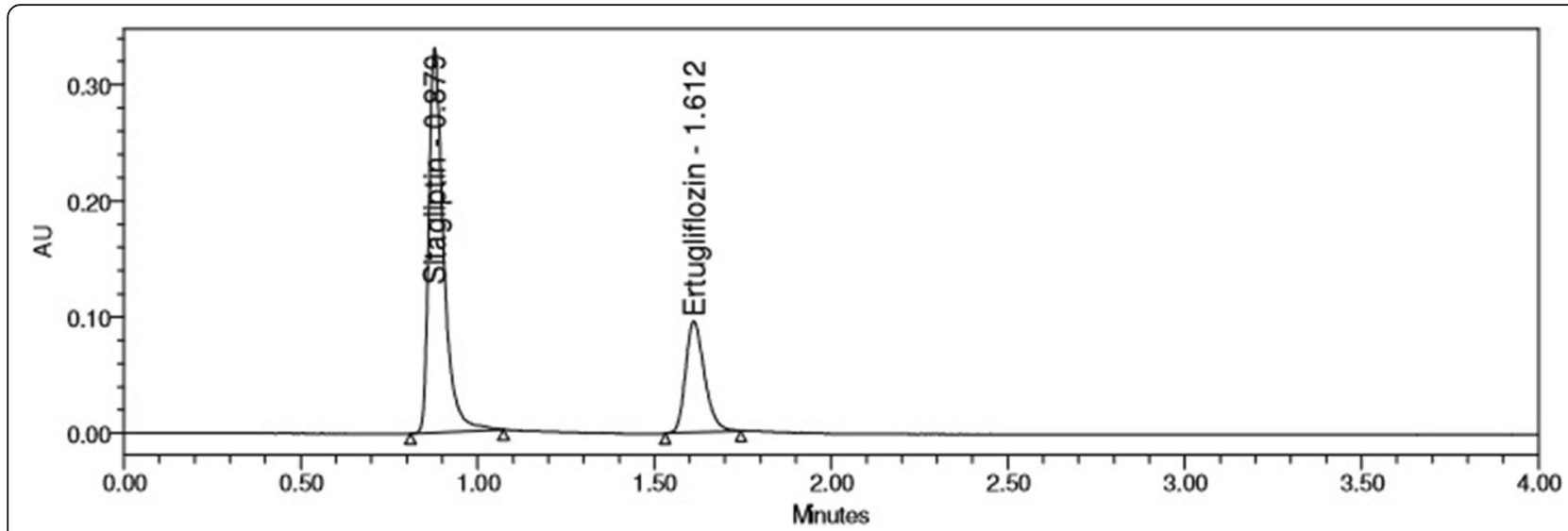

Fig. 4 Chromatogram of marketed formulation

\section{Method development}

Complete scrutinization of chromatographic parameters like column chemistry, mobile phase, column temperature, and flow rate aids in optimization of chromatographic conditions and to accomplish symmetric peak shape and better resolution of drugs. Mobile phase optimization was done with various combinations of suitable solvents in different ratios and finalized that acetonitrile: water $(\mathrm{pH} 3.5)(50: 50 \%, \mathrm{v} / \mathrm{v})$ as mobile phase with flow rate $0.2 \mathrm{ml} / \mathrm{min}$. Various trials were listed in Table 1. Optimized chromatogram as shown in Fig. 3. The marketed formulation chromatogram was shown in Fig. 4.

\section{Method validation}

The proposed method was validated as per ICH Q2R1 guidelines, and the method validation parameters include system suitability, linearity, precision, accuracy, robustness, and specificity.

\section{Linearity}

As per ICH, linearity is the ability of the analytical procedure to obtain test results that are directly proportional to the concentration of an analyte in the sample. The range is the interval from the upper concentration to the lower concentration of an analyte in the sample, which indicates a suitable level of precision, accuracy,

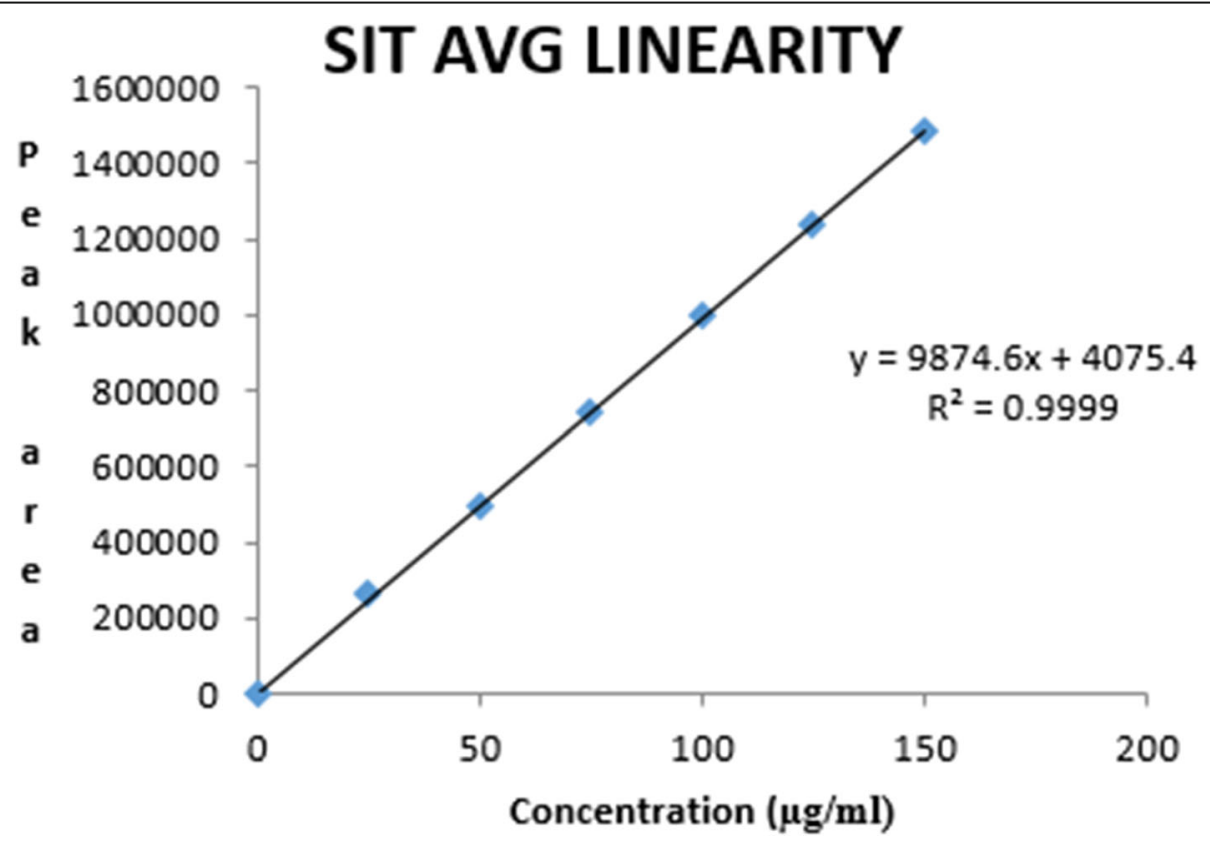

Fig. 5 Linearity data of sitagliptin 


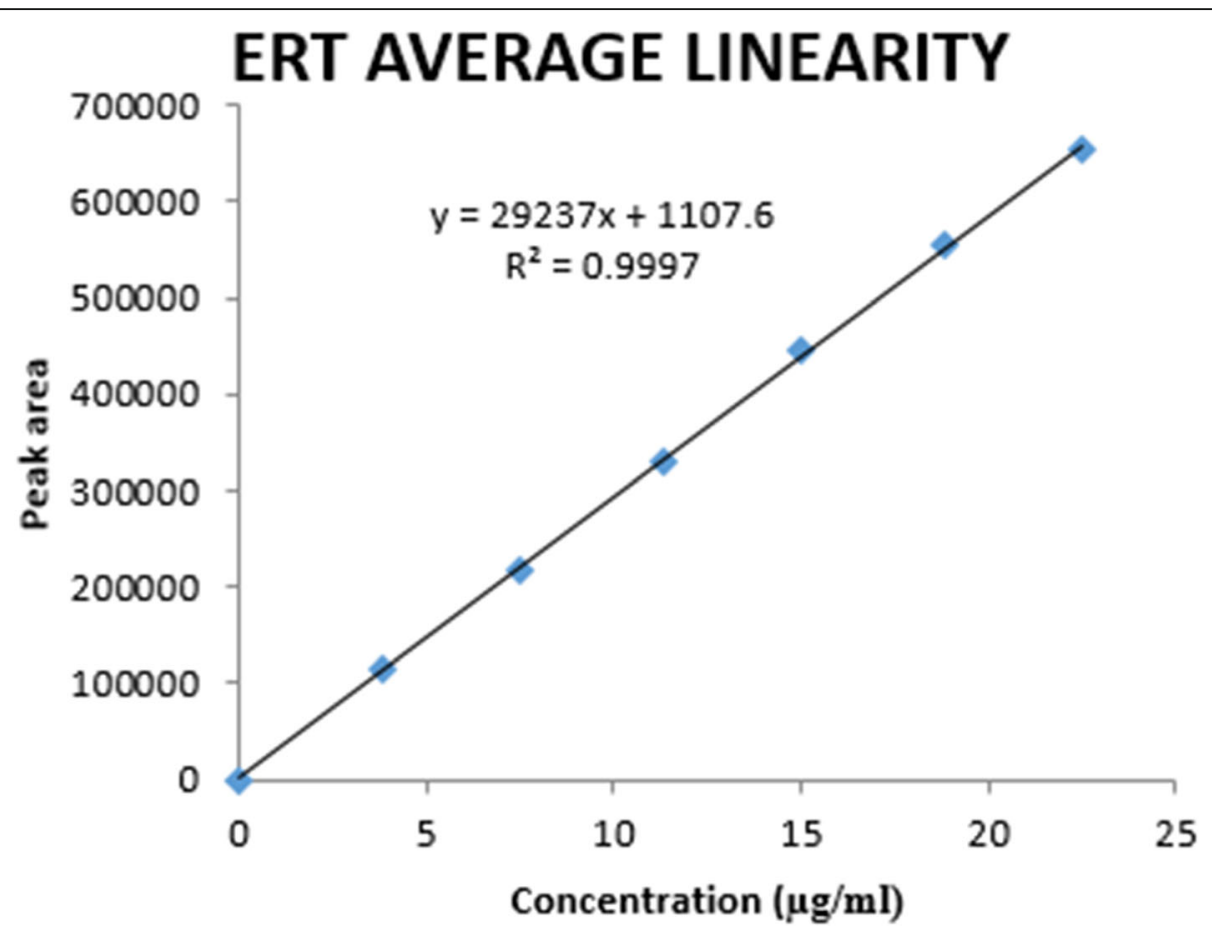

Fig. 6 Linearity data of ertugliflozin

and linearity in the analytical procedure. Linearity is determined by preparing aliquots at six different levels of calibration curve over the concentration range of 25$150 \mu \mathrm{g} / \mathrm{ml}$ for sitagliptin and $3.75-22.5 \mu \mathrm{g} / \mathrm{ml}$ for ertugliflozin and was analyzed in triplicate. The correlation coefficient with the regression line equation was determined from the calibration curve. Linearity data was shown in Figs. 5 and 6.

\section{Precision}

The precision of analysis was performed in terms of intra-day precision and inter-day precision. Precision is expressed in terms of relative standard deviation.

\section{Accuracy}

Accuracy is expressed in terms of recovery. It is determined by spiking a known amount of standard SIT and ERT to pre-analyzed samples at three different levels

Table 2 Linear regression data for calibration curves $(n=3)$

\begin{tabular}{lll}
\hline Parameters (units) & SIT & ERT \\
\hline Linearity range $(\mu \mathrm{g} / \mathrm{ml})$ & $25-150$ & $3.8-22.5$ \\
$r^{2} \pm$ SD & $0.9998 \pm 0.0001$ & $0.9996 \pm 0.0001$ \\
Slope $\pm S D$ & $9874.6 \pm 35.3$ & $29236.7 \pm 37.8$ \\
Intercept $\pm S D$ & $4074.5 \pm 1444.9$ & $1107.6 \pm 972.2$
\end{tabular}

SIT sitagliptin, ERT ertugliflozin, $n$ number of determinations, $\mu \mathrm{g} / \mathrm{m} / \mathrm{microgram}$ per milliliter, $r$ correlation coefficient, $S D$ standard deviation such as $50 \%, 100 \%$, and $150 \%$, and the percentage recovery was determined.

\section{LOD and LOQ}

As per $\mathrm{ICH}$, the limit of detection is the lowest amount of analyte that can be detected but not necessarily quantitated. The limit of quantification is the lowest amount of analyte in a sample that can be quantitatively determined with suitable precision and accuracy. LOD and LOQ were calculated using the following formula.

$$
\begin{aligned}
& \mathrm{LOD}=3.3 \sigma / S \\
& \mathrm{LOQ}=10 \sigma / S
\end{aligned}
$$

$S$ is the mean of the slope, and $\sigma$ is the standard deviation of the intercept.

LOD and LOQ were estimated, using the calculations from the calibration curve based on the

Table 3 Intra-day and inter-day precision of sitagliptin ( $n=6)$

\begin{tabular}{lllllll}
\hline Drug & Concentration & \multicolumn{2}{l}{ Intra-day precision } & & \multicolumn{2}{l}{ Inter-day precision } \\
\cline { 3 - 4 } & & Mean \pm SD & \%RSD & & Mean \pm SD & \%RSD \\
\hline Sitagliptin & $100 \mathrm{mg}$ & $994622.3 \pm 3381.02$ & 0.3 & & $956575.2 \pm 1926.26$ & 0.2
\end{tabular}

$n$ number of determinations, $S D$ standard deviation, $R S D$ relative standard deviation, $\%$ percentage, $\mathrm{mg}$ milligram 
Table 4 Intra-day and inter-day precision of ertugliflozin ( $n=6)$

\begin{tabular}{|c|c|c|c|c|c|}
\hline \multirow[t]{2}{*}{ Drug } & \multirow[t]{2}{*}{ Concentration } & \multicolumn{2}{|l|}{ Intra-day precision } & \multicolumn{2}{|c|}{ Inter-day precision } \\
\hline & & Mean \pm SD & \%RSD & Mean $\pm S D$ & \%RSD \\
\hline Ertugliflozin & $15 \mathrm{mg}$ & $448530.5 \pm 1775.14$ & 0.3 & $434201 \pm 2558.45$ & 0.5 \\
\hline
\end{tabular}

standard deviation of response and slope of the calibration curve.

\section{Forced degradation studies}

Forced degradation studies were conducted to assess the stability-indicating property of the proposed method [20]. Various stress studies conducted were acid hydrolysis $\left(0.5 \mathrm{~N} \mathrm{HCl} / 60^{\circ} \mathrm{C} / 1 \mathrm{~h}\right)$, base hydrolysis $\left(0.5 \mathrm{~N} \mathrm{NaOH} / 60^{\circ} \mathrm{C} / 1 \mathrm{~h}\right)$, oxidation $\left(10 \% \mathrm{H}_{2} \mathrm{O}_{2} / 60^{\circ} \mathrm{C} /\right.$ $1 \mathrm{~h})$, hydrolytic degradation (water $/ 60^{\circ} \mathrm{C} / 1 \mathrm{~h}$ ), photolysis (UV energy- $254 \mathrm{~nm} / 3$ days/dark control), and thermal degradation $\left(105^{\circ} \mathrm{C} / 75 \% \mathrm{RH} / 24 \mathrm{~h}\right)$. Forced degradation studies conducted at distinct stress conditions to assess the stability of drug products at various stress conditions provide information about the stability of SIT and ERT.

\section{Results}

\section{Linearity}

The linearity of SIT and ERT was found over the concentration range of $25-150 \mu \mathrm{g} / \mathrm{ml}$ and $3.75-22.5 \mu \mathrm{g} / \mathrm{ml}$, respectively, with the regression equation and correlation coefficients $y=9874.6 x+4075.4,0.9999$ for SIT, and $y=2937 x+1107.6,0.9997$ for ERT. Linearity data of SIT and ERT was listed in Table 2.

\section{LOD and LOQ}

LOD and LOQ were found to be $0.48 \mu \mathrm{g} / \mathrm{ml}$ and $1.46 \mu \mathrm{g} /$ $\mathrm{ml}$ for SIT and $0.11 \mu \mathrm{g} / \mathrm{ml}$ and $0.33 \mu \mathrm{g} / \mathrm{ml}$ for ERT.

\section{Precision}

The results of intra-day and inter-day precision indicate \%RSD that was found in the range $0.2-0.3$ for SIT and 0.3-0.5 for ERT, hence the method was found to be precise. Results of intra-day and inter-day precision were summarized in Tables 3 and 4.

Table 5 Accuracy of the developed method for sitagliptin ( $n=3$ )

\begin{tabular}{llllll}
\hline Drug & $\begin{array}{l}\text { Level of } \\
\text { addition }\end{array}$ & $\begin{array}{l}\text { Amount } \\
\text { added } \\
\mathbf{( \% )}\end{array}$ & $\begin{array}{l}\text { Drug found } \\
\mathbf{( m g} / \mathbf{m l})\end{array}$ & $\begin{array}{l}\text { \% Recovery } \\
\text { Mean } \pm \text { SD }\end{array}$ & $\begin{array}{l}\text { Average \% } \\
\text { recovery }\end{array}$ \\
\hline Sitagliptin & 50 & 50 & $50.1 \pm 0.26$ & $100.2 \pm 0.51$ & $100.2 \pm 0.57$ \\
& 100 & 100 & $99.7 \pm 0.5$ & $99.7 \pm 0.5$ & \\
& 150 & 150 & $151.1 \pm 0.26$ & $100.7 \pm 0.17$ & \\
\hline
\end{tabular}

$n$ number of determinations, \% percentage, $\mathrm{mg} / \mathrm{m} / \mathrm{milligram}$ per milliliter, $S D$ standard deviation, $m g$ milligram
Table 6 Accuracy of the developed method for ertugliflozin $(n=3)$

\begin{tabular}{|c|c|c|c|c|c|}
\hline Drug & $\begin{array}{l}\text { Level of } \\
\text { addition } \\
\text { (\%) }\end{array}$ & $\begin{array}{l}\text { Amount } \\
\text { added } \\
(\mathrm{mg})\end{array}$ & $\begin{array}{l}\text { Drug found } \\
\text { (mg/ml) } \\
\text { Mean } \pm \text { SD }\end{array}$ & $\begin{array}{l}\text { \% Recovery } \\
\text { Mean } \pm \text { SD }\end{array}$ & $\begin{array}{l}\text { Average } \% \\
\text { recovery } \\
\text { Mean } \pm S D\end{array}$ \\
\hline \multirow[t]{3}{*}{ Ertugliflozin } & 50 & 7.5 & $7.5 \pm 0.01$ & $99.8 \pm 0.28$ & $99.7 \pm 0.42$ \\
\hline & 100 & 15 & $14.9 \pm 0.1$ & $99.8 \pm 0.65$ & \\
\hline & 150 & 22.5 & $22.4 \pm 0.04$ & $99.4 \pm 0.18$ & \\
\hline
\end{tabular}

$n$ number of determinations, \% percentage, $\mathrm{mg} / \mathrm{m} /$ milligram per milliliter, $S D$

standard deviation, $\mathrm{mg}$ milligram

\section{Accuracy}

The accuracy of the method was studied through recovery studies at different spiking levels, i.e., 50\%, $100 \%$, and $150 \%$. The mean $\%$ recovery of SIT and ERT was found to be 100.2 and 99.7 with \%RSD 0.6 and 0.4 , respectively. Results of accuracy values were listed in Tables 5 and 6.

\section{Robustness}

As a part of robustness, with small and deliberate changes in mobile phase ratio, column temperature, and flow rate, there are no significant variation in peak area and resolution between SIT and ERT. Robustness data was given in Tables 7 and 8 .

\section{Assay}

The assay of the pharmaceutical formulation was carried out with \% RSD 0.3 and 0.4 for SIT and ERT, respectively, which indicate no peak interference at a retention time of SIT and ERT from excipients, impurities, and degradants.

\section{Forced degradation studies}

Forced degradation studies were carried out by exposing the sample solutions at various stress conditions. Degradation studies revealed that SIT was degraded in acidic, alkaline, peroxide, and thermal conditions, and ERT was degraded in acidic, alkaline, peroxide, and thermal conditions. Degradation chromatograms under acidic, basic, peroxide, and thermal conditions were shown in Figs. 7, 8, 9, and 10. No degradation peak was observed in hydrolytic and

Table 7 Robustness of sitagliptin $(n=6)$

\begin{tabular}{lll}
\hline Parameter & Peak area (mean \pm SD) & \%RSD \\
\hline Flow rate minus & $1310994 \pm 4100.3$ & 0.3 \\
Flow rate plus & $786560.8 \pm 2684.2$ & 0.3 \\
Mobile phase minus & $962983.3 \pm 3338.3$ & 0.3 \\
Mobile phase plus & $995949.2 \pm 9458.3$ & 0.9 \\
Thermal minus & $988393.2 \pm 5545.8$ & 0.6 \\
Thermal plus & $959826.3 \pm 1235$ & 0.1 \\
\hline
\end{tabular}

$n$ number of determinations, $S D$ standard deviation, $R S D$ relative standard deviation 
Table 8 Robustness of ertugliflozin $(n=6)$

\begin{tabular}{lll}
\hline Parameter & Peak area (mean \pm SD) & \%RSD \\
\hline Flow rate minus & $584073.2 \pm 5999.8$ & 1.0 \\
Flow rate plus & $351840.2 \pm 1790.2$ & 0.5 \\
Mobile phase minus & $432139.7 \pm 848.2$ & 0.2 \\
Mobile phase plus & $435316 \pm 4885.4$ & 1.1 \\
Thermal minus & $444698 \pm 1610.8$ & 0.4 \\
Thermal plus & $356581.5 \pm 717.5$ & 0.2
\end{tabular}

$n$ number of determinations, SD standard deviation, $R S D$ relative standard deviation

photodegradation conditions for SIT and ERT. The results of the degradation data were summarized in Table 9.

\section{Discussion}

Mobile phase optimization was given a prime preference for efficient resolution of SIT and ERT. The $\mathrm{pH}$ of the water and organic content of the mobile phase was optimized for symmetric peak and efficient resolution of chromatographic peaks. SIT and ERT were eluted at retention time $0.859 \mathrm{~min}$ and $1.570 \mathrm{~min}$. Method development for simultaneous estimation of SIT and ERT was done at a maximum wavelength of $218 \mathrm{~nm}$. An efficient chromatographic separation of both SIT and ERT was done with mobile phase acetonitrile: water $(\mathrm{pH} 3.5)[50: 50 \%, \mathrm{v} / \mathrm{v}]$ and waters HibarC8 $[100 \times 2.1 \mathrm{~mm}, 2 \mu$ particle size $]$ column and flow rate $0.2 \mathrm{ml} / \mathrm{min}$. Linearity data with a correlation coefficient value of 0.999 indicate a good correlation over the linear concentration range. \% RSD of SIT and ERT for both intra-day and inter-day precision ranges from $0.2-0.3$ and $0.3-0.5$ and indicates repeatability of the analytical method. LOD of the proposed analytical method represents that the method was highly sensitive. The recovery of the spiked SIT and ERT was found to be 100.2 and 99.7, which represents that the proposed method has ample accuracy as per ICH guidelines. Small deliberate changes in the method parameters could not affect the results of system suitability parameters, and it is illustrated by the robustness of the proposed method. From the forced degradation conditions, it was observed that no degradation under hydrolytic and photodegradation conditions. As per ICH guidelines, the limit of acceptable forced degradation is less than $20 \%$. In the proposed method, the degradation of SIT and ERT was less than 20\%, which represents the stability-indicating method.

In the previously reported work, the retention time of SIT (4.60 min) and ERT (2.39min) was high [15], apart from that the LOD and LOQ concentrations were too high in the reported method for SIT and ERT. In the present method, the retention time was improved and the LOD and LOQ concentrations were

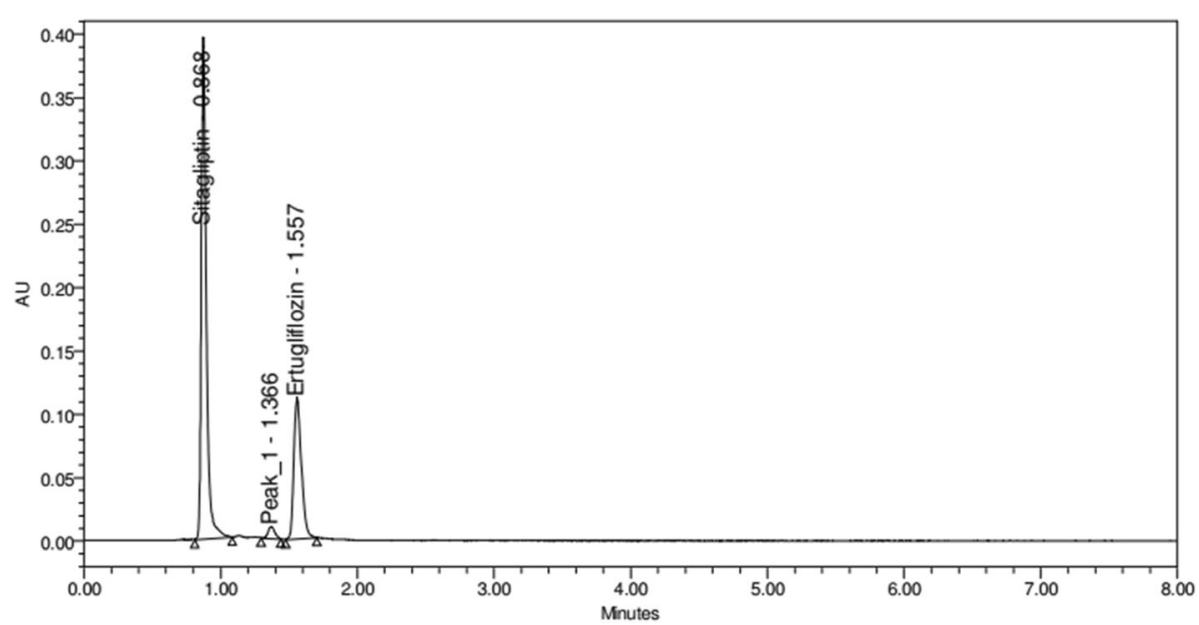

Fig. 7 Chromatogram of acid degradation solution 


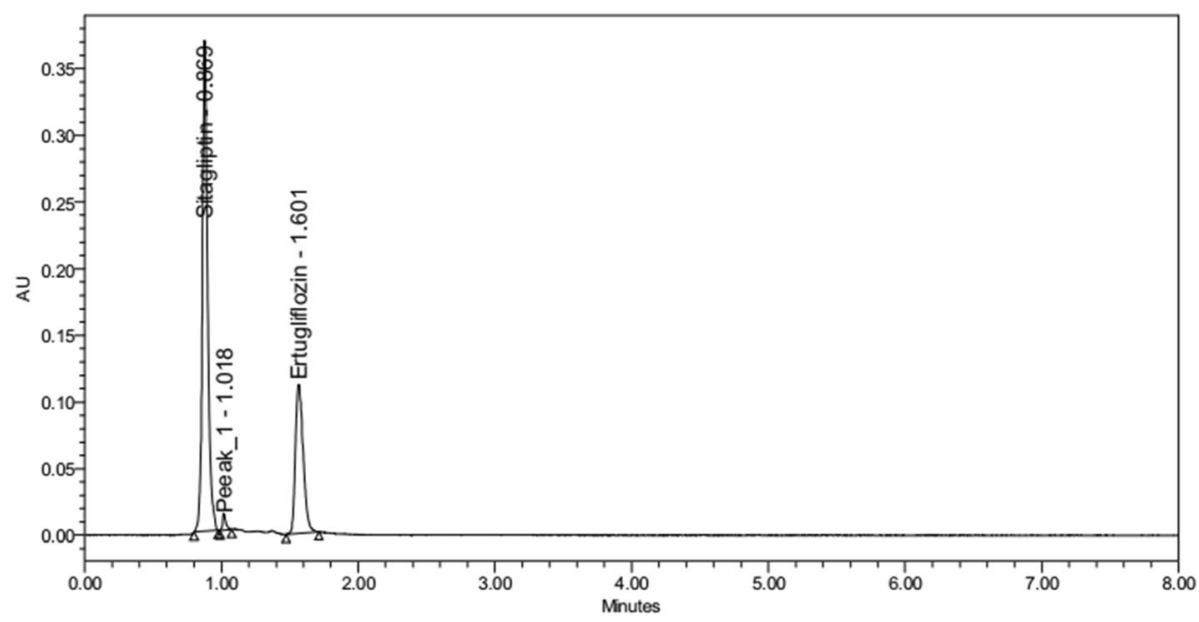

Fig. 8 Chromatogram of alkaline degradation solution

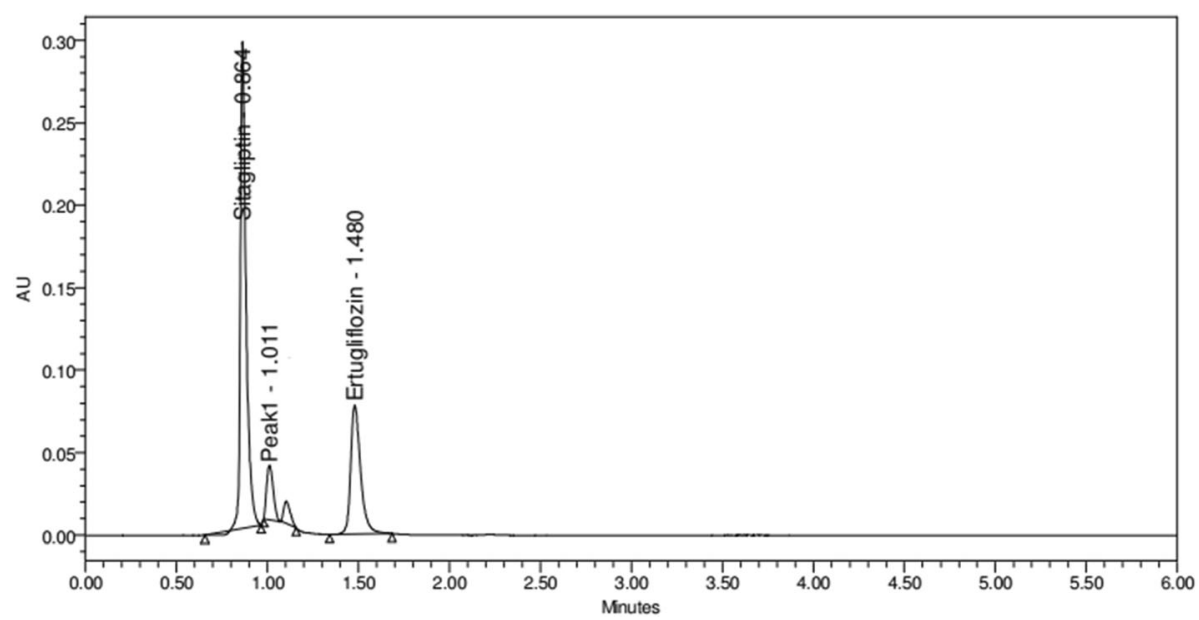

Fig. 9 Chromatogram of peroxide degradation solution

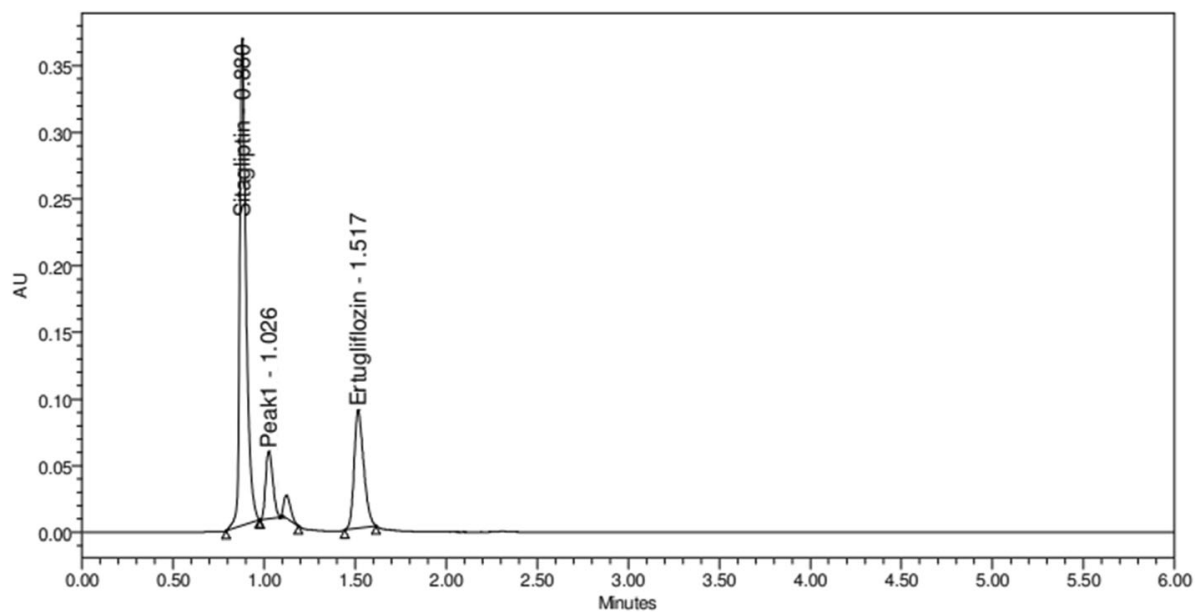

Fig. 10 Chromatogram of thermal degradation solution 
Table 9 Summary of degradation data of SIT and ERT

\begin{tabular}{lllll}
\hline Degradation condition & $\begin{array}{l}\% \\
\text { Degradation }\end{array}$ & $\begin{array}{l}\boldsymbol{R}_{\mathrm{t}} \text { (min) of } \\
\text { degradation } \\
\text { products }\end{array}$ \\
\cline { 2 - 3 } & SIT & ERT & Peak 1 \\
\hline Acid $\left(0.5 \mathrm{~N} / 60^{\circ} \mathrm{C} / 1 \mathrm{hr}\right)$ & 8.8 & 10.5 & 1.366 \\
Base $\left(0.5 \mathrm{~N} / 60^{\circ} \mathrm{C} / 1 \mathrm{hr}\right)$ & 6.1 & 9.7 & 1.108 \\
Oxidative $\left(10 \% \mathrm{~W} / \mathrm{V} \mathrm{H}_{2} \mathrm{O}_{2} / 60^{\circ} \mathrm{C} / 1 \mathrm{hr}\right)$ & 8.1 & 6.2 & 1.011 \\
Hydrolytic $\left(\right.$ water $\left./ 60^{\circ} \mathrm{C} / 1 \mathrm{hr}\right)$ & 1.8 & 1 & $\ldots$ \\
Thermal $\left(105^{\circ} \mathrm{C} / 1\right.$ day) & 8.4 & 11.1 & 1.026 \\
Photolytic $\left(\mathrm{UV}\right.$ radiation at $200-\mathrm{Wh} / \mathrm{m}^{2}-$ & 8.2 & 11.3 & $\ldots$ \\
dark control) & & &
\end{tabular}

SIT sitagliptin, ERT ertugliflozin, $h r$ hour, \% percentage, $R_{t}$ retention time, $\%$ percentage, UV ultraviolet, $\min$ minute, $N$ normality, ${ }^{\circ} \mathrm{C}$, degree Celsius, $W h / \mathrm{m}^{2}$ Watt-hour per square meter

also too low. A comparison was made between the present method and already reported the method in Table 10.

\section{Conclusion}

The present UPLC method adopted high sensitivity and accuracy forth estimation of SIT and ERT in bulk and pharmaceutical formulation. The validation of the current method was done as per ICH Q2R1 guidelines. The proposed method was remarkable to previous methods in terms of validation parameters and stability-indicating studies. Validation parameters like LOD, LOQ, and precision results were in the acceptable range, which indicate that the instrument is capable to give reproducible result at the lowest concentration. Degradation studies could conclude that degradation peaks of SIT and ERT did not interfere with the retention time of SIT and ERT peaks. Hence, it demonstrated that the proposed method is rapid and stability-indicating and it can be used successfully for the quality control analysis of SIT and ERT in bulk and pharmaceutical formulation.

Table 10 Comparison between the present method with the reported method

\begin{tabular}{|c|c|c|c|c|}
\hline \multirow[t]{2}{*}{ Parameter } & \multicolumn{2}{|c|}{ Present method } & \multicolumn{2}{|c|}{ Reported method } \\
\hline & Sitagliptin & Ertugliflozin & Sitagliptin & Ertugliflozin \\
\hline Retention time & $0.859 \mathrm{~min}$ & $1.570 \mathrm{~min}$ & $4.60 \mathrm{~min}$ & $2.39 \mathrm{~min}$ \\
\hline LOD & $0.5 \mu \mathrm{g} / \mathrm{ml}$ & $0.13 \mu \mathrm{g} / \mathrm{ml}$ & $12.71 \mu \mathrm{g} / \mathrm{ml}$ & $42.37 \mu \mathrm{g} / \mathrm{ml}$ \\
\hline LOQ & $1.53 \mu \mathrm{g} / \mathrm{ml}$ & $0.38 \mu \mathrm{g} / \mathrm{ml}$ & $8.59 \mu \mathrm{g} / \mathrm{ml}$ & $28.65 \mu \mathrm{g} / \mathrm{ml}$ \\
\hline $\begin{array}{l}\text { Mobile } \\
\text { composition }\end{array}$ & \multicolumn{2}{|c|}{$\begin{array}{l}\text { Acetonitrile to water }(\mathrm{pH} 3.5) \\
(50: 50 \%, \mathrm{v} / \mathrm{v})\end{array}$} & \multicolumn{2}{|c|}{$\begin{array}{l}0.5 \mathrm{mM} \text { potassium } \\
\text { dihydrogen ortho phosphate } \\
\text { buffer: Methanol }(55: 45 \mathrm{v} / \mathrm{V})\end{array}$} \\
\hline Flow rate & \multicolumn{2}{|l|}{$0.2 \mathrm{ml} / \mathrm{min}$} & \multicolumn{2}{|l|}{$1 \mathrm{ml} / \mathrm{min}$} \\
\hline Column & \multicolumn{2}{|c|}{$\mathrm{c} 8(100 \times 2.1 \mathrm{~mm}, 2 \mu \mathrm{m})$} & \multicolumn{2}{|c|}{$\mathrm{C} 18(250 \times 4.6 \mathrm{~mm}, 5 \mu \mathrm{m})$} \\
\hline
\end{tabular}

$L O D$ limit of detection, $L O Q$ limit of quantification, min minute, $\mu g$ microgram, $m /$ milliliter, $v / v$ volume by volume, $\mathrm{mm}$ millimeter, $\mu \mathrm{m}$ micrometer, $\%$ percentage

\section{Abbrevations}

RP-UPLC: Reverse phase ultra-performance liquid chromatography; TUV: Thermal ultraviolet; ICH: International council for harmonization; LOD: Limit of detection; LOQ: Limit of quantification; T2DM: Type 2 diabetes mellitus; SIT: Sitagliptin; ERT: Ertugliflozin; DPP: Dipeptidyl peptidase; FDA: Food and Drug Administration; GLP: Glucagon-like peptide; SGLT: Sodium-glucose cotransporter; SBP: Systolic blood pressure DBP: Diastolic blood pressure; HPLC: High-performance liquid chromatography; LC-MS: Liquid chromatography-mass spectrometry

\section{Acknowledgements}

The authors gratefully acknowledge the Fortune Pharma Pvt., Ltd, Hyderabad, for providing drug samples, to carry forward the research work.

\section{Authors' contributions}

RB analyzed and interpreted the data of obtained chromatograms and a major contributor in writing the manuscript. SA performed the benchwork and experimental work of the stability-indicating liquid chromatographic method development of analytes using UPLC. The authors read and approved the final manuscript.

\section{Funding}

It is self-financed, and the funding was not sponsored by any organization, funding agency, and non-profit research bodies.

Availability of data and materials

All data and material should be available upon request.

\section{Declarations}

Ethics approval consent to participate

Not applicable.

\section{Consent for publication}

Not applicable.

\section{Competing interests}

No competing interests to declare.

\section{Author details}

${ }^{1}$ Department of Pharmacognosy, IPT, SPMW, Tirupati, Andhra Prade sh-517501, India. ²Department of Pharmaceutical Analysis, IPT, SPMW,

Tirupati, Andhra Prade sh-517501, India.

Received: 30 July 2020 Accepted: 17 March 2021

Published online: 12 April 2021

\section{References}

1. Gallwitz G (2007) Review of sitagliptin phosphate: a novel treatment for type-2 diabetes. Vasc Health Risk Manag 3(2):203-210. https://doi.org/10.214 7/vhrm.2007.3.2.203

2. Mega C, Lemos ETD, Fernandes R, Reis F (2017) Renoprotective effects of the dipeptidyl peptidase-4 inhibitor sitagliptin: a review in type 2 diabetes. J Diabetes Res:1-14. https://doi.org/10.1155/2017/5164292

3. Gadsby R (2009) Efficacy and safety of sitagliptin in the treatment of type 2 diabetes. Clin Med Ther 1:53-62

4. Cinti F, Moffa S, Impronta F, Cefalo CMA, Vinsin AS, Sorice GP, Teresa M Giaccari A (2017) Spotlight on ertugliflozin and its potential in the treatment of type 2 diabetes: evidence to date. Drug Des Dev Ther 11: 2905-2919. https://doi.org/10.2147/DDDT.S114932

5. McNeill AM, Davies G, Kruger E, Kowal S (2019) Ertugliflozin compared to other anti-hyperglycemic agents as monotherapy and add-on therapy in type-2 diabetes: a systemic literature review and network meta-analysis. Diabetes Ther 10(2):473-491. https://doi.org/10.1007/s13300-019-0566-x

6. Madhuri AH, Patel KV (2016) Development and validation of spectrophotometric method for metformin and sitagliptin by absorption ratio method. J Pharm Sci Bioscientific Res 6:733-739

7. Inamdar HP, Mhaske AA (2012) RP-HPLC method for simultaneous determination of metformin hydrochloride, rosiglitazone and sitaglipin application to commercially available drug products. Int J Pharm Sci Res 3 : $3267-3276$ 
8. Chavan V, Ghante M, Sawant S (2014) Development and validation of RPHPLC method for simultaneous estimation of sitagliptin phosphate and simvastatin in bulk and dosage form. J App Pharm 6:327-338

9. Lavanya R, Yonus M (2013) Development and validation of RP-HPLC method for the estimation of sitagliptin phosphate in bulk and its tablet dosage form. J Adv Pharm Edu Res 3:475-479

10. Lakshmi ES, Sravya E, Sireesha D, Vasudha B (2017) Development and validation of RP-HPLC method for estimation of sitagliptin phosphate in tablet dosage form. Int J App Pharm Sci Res 2(03):41-45. https://doi.org/1 0.21477/ijapsr.v2i3.8099

11. Karimulla SK, Vasanth PM, Ramesh T, Ramesh M (2013) Method development and validation of sitagliptin and metformin using reverse phase HPLC method in bulk and tablet dosage form. Der Pharmacia Lettre 5:168-174

12. Sankar ASK, Suraj S, Jhansi A, Shanmugasundaram P, Sumithra M (2013) Development and validation for simultaneous estimation of sitagliptin and metformin in pharmaceutical dosage form using RP-HPLC method. Int J Pharm Tech Res 5:1736-1744

13. Ravisankar P, Hassain SK, Neeha SKM (2015) Novel RP-HPLC method for simultaneous determination of sitagliptin and simvastatin in bulk and dosageform. IOSR J Pharm 5:34-40

14. Venkateswararao P, Lakshman Rao A, Prasad SVUM (2019) Development and validation of new stability indicating reverse phase high performance liquid chromatography method for simultaneous determination of metformin hydrochloride and ertugliflozin in bulk and pharmaceutical dosageform. Asian J Pharm Clin Res 12:235-240. https://doi.org/10.5281/zenodo.1220228

15. Chinababu D, Madhusudhanachetty C, Mastanamma SK (2018) Novel stress indicating RP-HPLC method development and validation for the simultaneous estimation of ertugliflozin and sitagliptin in bulk and its formulation. Orient J Chem 34(5):2554-2561. https://doi.org/10.13005/ ojc/340543

16. Bonde SL, Bhadane RP, Avinash G, Deepak K, Sumit G, Narendiran AS (2013) A simple and sensitive method for determination of metformin and sitagliptin in human plasma using liquid chromatography and tandem mass spectrometry. Int J Pharm Pharm Sci 5:463-470

17. Srinivas R, Imran A, labal A, Arindam M, Saral T (2015) Development and validation of a method for simultaneous estimation of metformin and sitagliptin in human plasma by LC-MS-MS and its application in bioequivalence study. J Chromatogr Sci 53(9):1549-1556. https://doi.org/10.1 093/chromsci/bmv055

18. ICH Harmonized Tripartite (2005) Validation of analytical procedures: text and methodology Q2 (R1). International Conference on Harmonization, Geneva Availablefrom:http://www.ich.org/fileadmin/public_web_site/ICH_ Products/Guidelines/Quality/Q2_R1/Step4/Q2_R1_Guideline.pdf. (Accessed 12 Mar 2020)

19. ICH Harmonized Tripartite. Stability testing of new drug substance and products. Q1A(R2), 2003. Availablefrom:http://www.ich.org/fileadmin/public_ web_site/ICH_Products/Guidelines/Quality/Q1A_R2_Guideline.pdf. (Accessed 12 Mar 2020)

20. Blessy M, Ruchi DP, Prajesh NP, Agarwal YK (2014) Development of forced degradation and stability indicating studies of drugs- A review. J Pharm Anal 4(3):159-165. https://doi.org/10.1016/j.jpha.2013.09.003

\section{Publisher's Note}

Springer Nature remains neutral with regard to jurisdictional claims in published maps and institutional affiliations.

\section{Submit your manuscript to a SpringerOpen ${ }^{\circ}$ journal and benefit from:}

- Convenient online submission

- Rigorous peer review

- Open access: articles freely available online

- High visibility within the field

- Retaining the copyright to your article

Submit your next manuscript at $\boldsymbol{\nabla}$ springeropen.com 